Case Report

\title{
MICROBIOLOGICAL ASPECTS OF PULMONARY INFECTION WITH ACTINOMYCES ODONTOLYTICUS
}

Snezana Ivic-Kolevska ${ }^{1}$, Andreja Arsovski ${ }^{1}$

1 Private Health Institution "Re-Medika", Skopje, Republic of North Macedoniaa

Citation: Ivic-Kolevska S; Arsovski A. Microbiological aspects of pulmonary infection with Actinomyces odontolyticus - case report. Arch Pub Health 2021; 13 (1).

doi.org/10.3889/aph.2021.5936

Key words: actinomycosis, penicillin, pulmonary infection.

*Correspondence: Snezana Ivic-Kolevska. Private Health Institution "Re-Medika", Skopje, Republic of North Macedonia E-mail: snezanaivickolevska@ hotmail.com

Received: 20-Nov-2020; Revised: 15-Jan-2021 Accepted: 25-Fev-2021; Published: 10-Mar-2021 Copyright: 2021. Snezana Ivic-Kolevska, Andreja Arsovski. This is an open-access article distributed under the terms of the Creative Commons Attribution License, which permits unrestricted use, distri bution and reproduction in any medium provided he riginal author(s) and source are credited Competing Interests: The author have declared that no competing interests

Приказ на случај

\begin{abstract}
Pulmonary actinomycosis is a rare and uncommon invasive bacterial disease. We are presenting a case report of 45 year old male patient with severe acute pneumonia with pleural effusion, presenting with fever, fatigue, productive cough, chest pain, dyspnea and swelling on both legs. Microbiological findings showed an isolation of anaerobic bacterium Actinomyces odontolyticus. The antibiogram showed sensitivity on penicillin and penicillin preparations, cephalosporins and carbapenems. There was an intermediate sensitivity on quinolones and there was a resistance on lincosamins and aminoglycosides. Our patient was treated with operation and received appropriate antibiotic therapy, after which there was a very good improvement, both clinically and on control native lung RTGs. This disease has excellent prognosis with early detection and proper treatment. Penicillin is the drug of choice for treatment of pulmonary actinomycosis.
\end{abstract}

\section{МИКРОБИОЛОШКИ АСПЕКТИ НА БЕЛОДРОБНА ИНФЕКЦИЈА ПРЕДИЗВИКАНА СО ACTINOMYCES ODONTOLYTICUS}

Снежана Ивиќ-Колевска ${ }^{1}$, Андреја Арсовски

1 ПзУ Ре-Меgика, Скойје, Рейублика Северна Макеgонија

\begin{abstract}
Цитирање: Ивиќ-Колевска С, Арсовски А. Микробиолошки аспекти на белодробн инфекција предизвикана со Actinomyces odontolyticus - приказ на случај. Арх Ј Здравје 2021:13(1)

doi.org/10.3889/aph.2021.5936
\end{abstract}

Клучни зборови: актиномикоза, пеницилин, белодробна инфекција.

*Кореспонденција: Ивиќ-Колевска Снежана, Пзу Ре-Медика Скопје Република Северна Македонија. E-mail: snezanaivickolevska@ hotmail.com

Примено: 20-ноем-2020; Ревидирано: 15-јан-2021; Прифатено: 25-фев-2021; Објавено: 10-мар-2021

Печатарски права: 2021 Снежана Ивиќ-Колевска, Андреја Арсовски Оваа статија е со освска, Андреја Арсовски, Ова丿 статија е со не нелокализирана лиценца, која овозможува иеограничена употеба, дистрибуциј и репронеограничена употеба, дистрибуција и репродукција на било кој медиум, доколку се цитира ат оригиналниот(ите) автор(и) и изворот.

Конкурентски интереси: Авторот изјавува дека нема конкурентски интереси.

\section{Извадок}

Пулмоналната актиномикоза е ретка и невообичаена инвазивна бактериска болест. Ние претставуваме приказ на случај на 45-годишен машки пациент со тешка акутна пневмонија со плеврален излив, презентиран со треска, замор, продуктивна кашлица, болка во градите, диспнеа и оток на двете нозе. Микробиолошките наоди покажаа изолација на анаеробната бактерија Actinomyces odontolyticus. Антибиограмот покажа чувствителност на препаратите за пеницилин, цефалоспорини и карбапенеми. Имаше средна чувствителност на хинолоните и постоеше отпорност на линкозамини и аминогликозиди. Нашиот пациент беше третиран со операција и доби соодветна антибиотска терапија, по што имаше значително подобрување, и клинички и на контролните РТГ на белите дробови. Оваа болест има одлична прогноза со рано откривање и правилен третман. Пеницилин е лек по избор за третман на пулмонална актиномикоза. 


\section{Introduction}

Actinomycosis is a rare and uncommon invasive bacterial disease that has been recognized for over a century. Actinomycosis is a progressively invasive bacterial infection caused by organisms of the Actinomyces species. Actinomyces is a non-motile, filamentous, branching, gram-positive and predominantly anaerobic bacteria. These organisms belong to the phylum Actinobacteria, in the order Actinomycetales and family Actinomycetaceae ${ }^{1}$.

Over thirty species of Actinomyces have been described thus far, at least half of which are pathogenic to humans. ${ }^{[2]}$ The most common agents in this disease are A. israelii and A. gerencseriae (formerly A. Israelii serotype ${ }^{2}$ ), but other Actinomyces species such as: A. meyeri, A. naeslundii, A. viscosus, A. odontolyticus, A. neuii, A. turicensis, and $A$. radingae are important for human populations ${ }^{2}$. Actinomyces. israelii and Actinomyces gerencseriae are responsible for about $70 \%$ of orocervicofacial infections. Hematogenous dissemination of actinomycosis is extremely rare and has mainly been associated with $A$. meyeri, A. israelii, and A. odontolyticus ${ }^{3,4}$.

Most of the Actinomyces spp. are present in polymicrobial flora. Actinomyces infections could be polymicrobial and associated with other bacteria, named "companion microbes", which contribute to initiation and development of infection by inhibiting host defenses or reducing oxygen tension5.

Pathogenic Actinomyces species are not present freely in nature, but are commensals that inhabit the oropharynx, gastrointestinal tract and female genital tract of healthy hu- mans. ${ }^{[6,7]}$ The most common site of Actinomyces infection is the cervicofacial region (about $60 \%$ ), ${ }^{[8]}$ whereas actinomycosis of the middle ear and mastoid is a rare entity. To date, multiple different clinical features of actinomycosis have been described, as various anatomical sites (such as face, bone and joint, respiratory tract, genitourinary tract, digestive tract, central nervous system, skin, and soft tissue structures) can be affected. Actinomycosis often mimics malignancy, tuberculosis, or nocardiosis, as it spreads continuously and progressively, and can form a cold abscess $^{1,2}$. Difficulty in diagnosing the actinomycosis by bacterial cultures of clinical specimens has been attributed to the fact that most species are hard to grow on agar plates ${ }^{2,6}$.

\section{Case report}

At the Department of surgery, in PHO "Re-Medika", Skopje, Macedonia, in June 2016, a male patient at the age of 45 was hospitalized. Our patient had several risk-factors: obesity, insulindependent diabetes and high blood pressure. He presented at our department with fever, fatigue, respiratory problems such as productive cough, chest pain and dyspnea, as well as swelling on both legs.

At admission a biochemical analysis of blood count was made: Glycaemia $12 \mathrm{mmol} / \mathrm{L}, \mathrm{CRP} 382 \mathrm{mg} / \mathrm{L}, \mathrm{WBC}$ $23,0 \times 10^{9} / \mathrm{L}$, Granulocytes $21,3 \times 10^{9} / \mathrm{L}$, Lymfocytes-R 5,7 x109/L, Granulo-R

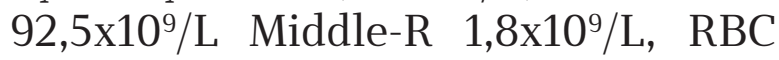
4,50x1012/L, HGB $125 \mathrm{~g} / \mathrm{L}$, Hematocrit 35,3\%, MCV 78,3fL, MCH 27,8pg, MCHC 355g/L, PLT 208x10 $9 / \mathrm{L}$.

A pleural puncture was made. There was about $300 \mathrm{ml}$ thick muddy con- 
tent with large whitish particles and detritus. The material was sent for cytological, microbiological and biochemical analysis.

Biochemical analysis of pleural punctate: Gly $0,01 \mathrm{mmol} / \mathrm{L}$, total proteins 44,6g/L, WBC 10,2x10\%/L, Gran 3,7x10\%/L, Lymf.-R 28,8x10\%/L, Gran-R

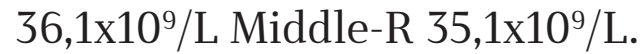

Cytological findings of pleural punctate: Microscopic examination of both made direct smears of submitted material identified cytomorfological elements of acute, abscess-like inflammation, constructed from leukotoxic debris with numerous granulocytes, macrophages, and rare small accumulations of eosinophilic finely granulated oval formations who seem to consist of colonies of Actinomyces.

Material for analysis in diagnostic microbiology laboratory was promptly and adequately microbiologically treated, and inoculated on adequate plates. For isolation of aerobic bacteria material was inoculated on Columbia blood agar (BioMerieux, France) and enriched with thioglycolate broth medium (BioMerieux, France). For isolation of anaerobic bacteria material was inoculated on Schaedler agar (BioMerieux, France) and for isolation of fungi on Candida agar (BioMerieux, France). From the same microbiological material a direct preparation was made which was stained by Gram. Columbia blood agar and enriching medium were incubated at $37^{\circ} \mathrm{C}$, while Candida agar was incubated at $25^{\circ} \mathrm{C}$ in aerobic conditions. Schaedler agar was incubated at $37^{\circ} \mathrm{C}$ in anaerobic conditions (provided with Gas-Pak system (BioMerieux, France). After an incubation of 24 hours on Columbia blood agar and Candida agar remained sterile.
Schaedler agar was first read after incubation of 48 hours there were tiny colonies who were colored as Gram positive. These colonies were processed on automated system VITEK 2 with adequate card for anaerobic bacteria (BioMerieux, France) and were identified as Actinomyces odontolyticus, which was very important for setting up a precise diagnosis and proper and adequate treatment of our patient. These microbiological results confirmed previous cytological findings.

From the enriching medium a subcultivation was made on adequate plate for isolation on aerobic and anaerobic bacterias and there was an isolation of anaerobic bacteria identified as Actinomycesodontolyticus. Aerobic bacteria were not isolated.

On direct preparation colored by Gram on microscop we detected a great number of white blood cells.

Antibiotic sensitivity of anaerobic bacteria Actinomyces odontolyticus has been studied with Disc-diffusion method on blood agar incubation in anaerobic conditions at $37^{\circ} \mathrm{C} 48$ hours. The pallet of antibiotics contained penicilins, cephalosporins, carbapenems, quinolones, lincosamines and aminoglycosides.

Microbiological diagnosis showed the following: there was no isolation of aerobic bacteria or yeasts. There was an isolation of anaerobic bacterium Actinomyces odontolyticus.The antibiogram showed sensitivity on penicillin and penicillin preparations, cephalosporins and carbapenems. There was an intermediate sensitivity on quinolones and there was a resistance on lincosamins and aminoglycosides. 


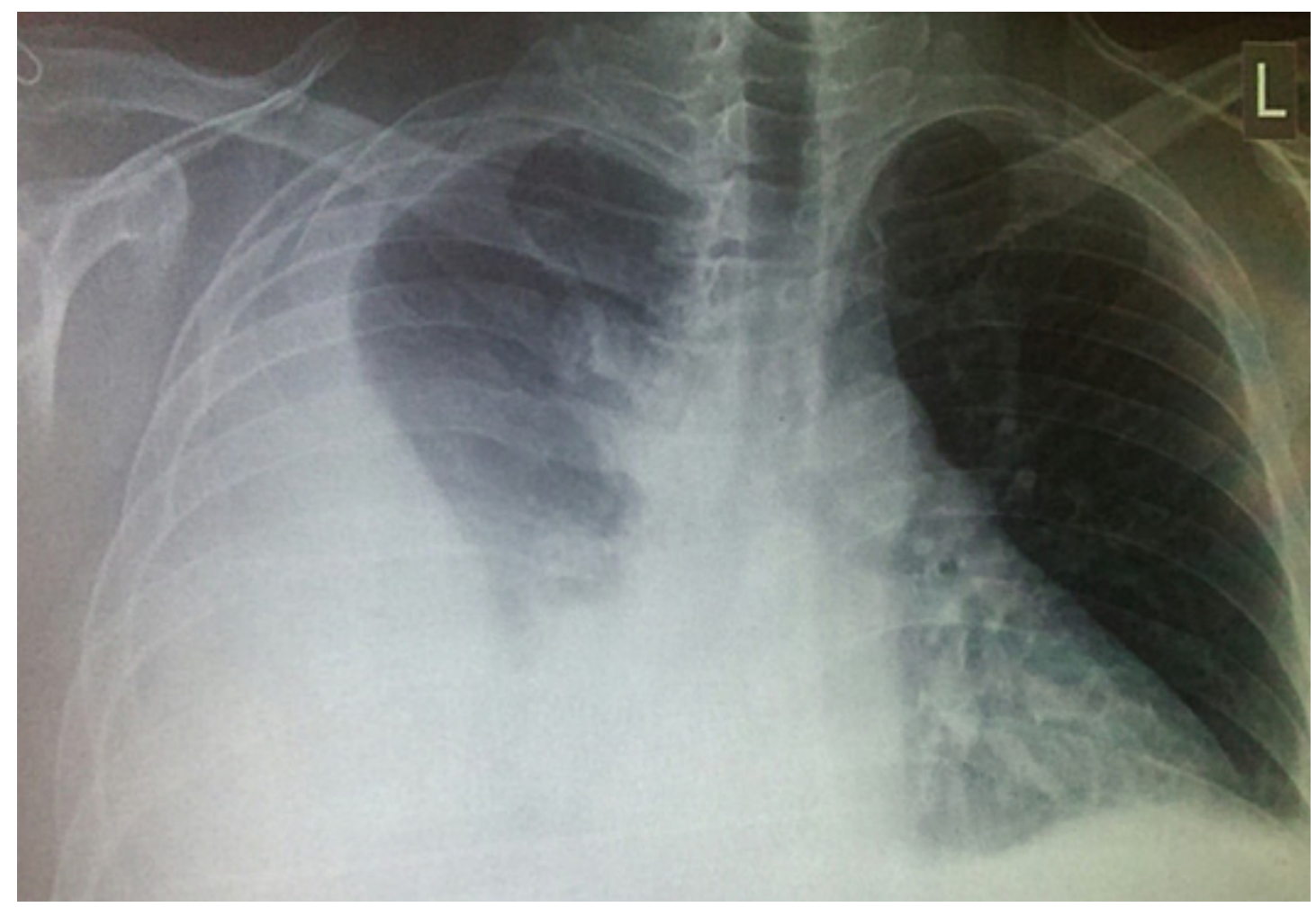

Figure 1: Native lung RTG at the admission

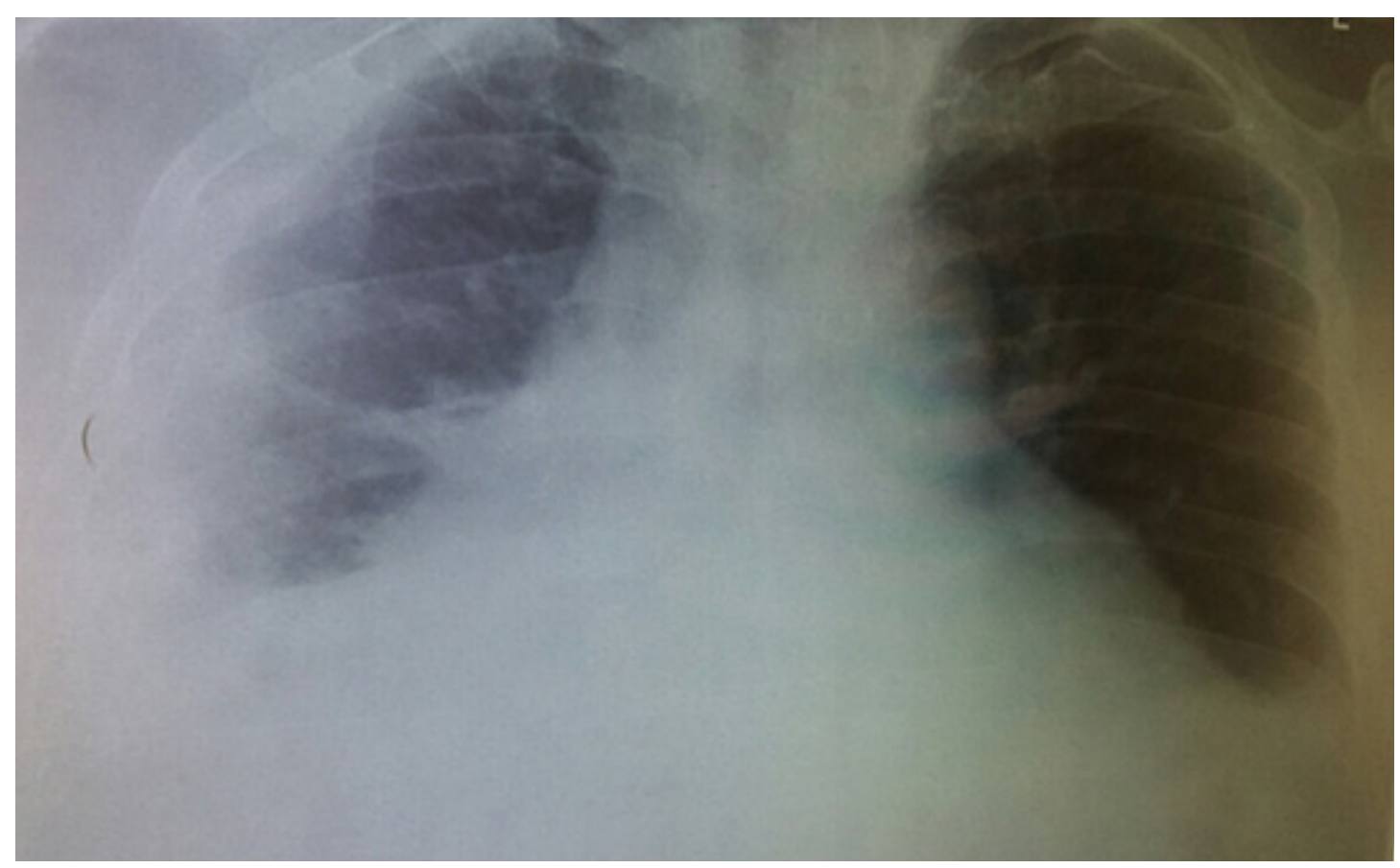

Figure 2: Control native lung RTG on one day after surgery 
Figure 3: Control native lung RTG on three days after surgery

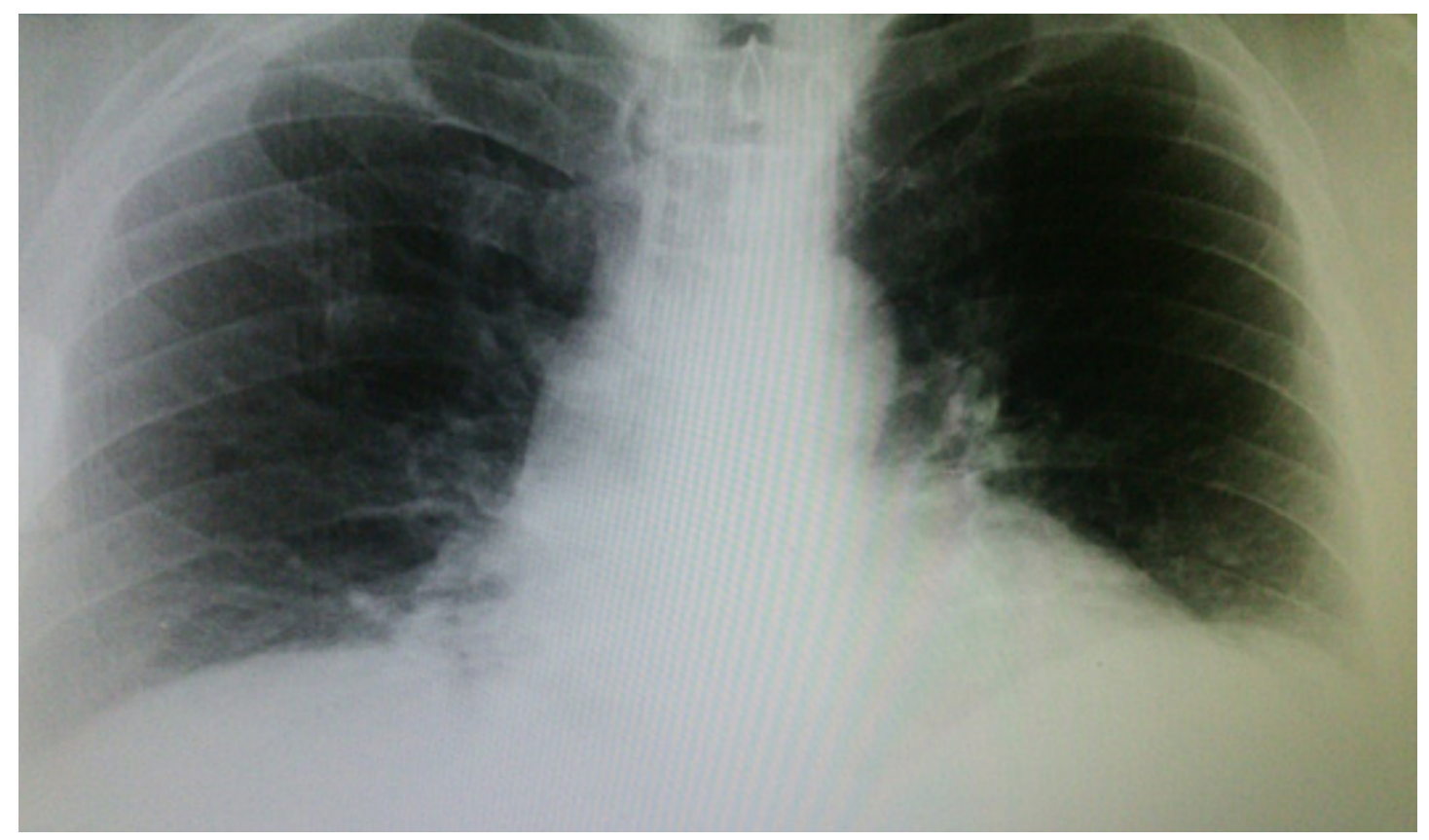

Figure 4: Native lung RTG on one year after surgery

Native lung RTG at the admission of the patient: On right basal and medium parties and in apical para-costal segment there is a homogeneous shadow of a large amount of pleural effusion with slight compression of the heart. On the left side there is a good lung transparency with discreet shading in the left frenico-costal sinus (Figure 1). 
After initial preparations a surgery with endotracheal anesthesia using a blocker tube was made. Intraoperatively there were small quantities of thick and yellowish gray liquid content, with fragments that are dense like jelly and numerous thick deposits on the visceral pleura and diaphragm.

During the surgery a punctate material was taken for microbiology analysis.

Postoperative recovery of the patient was good.

There was an improvement of laboratory findings. When the microbiological findings were done (with isolation of anaerobic bacterium Actinomyces odontolyticus), our patient received appropriate antibiotic therapy: crystal penicillin 20000000 I.U. every $6 \mathrm{~h}$ and amp. Ceftriaxon $2 \mathrm{~g} / 24 \mathrm{~h}$ for 14 days. After that the patient was sent home in good condition, with prolonged antibiotic therapy: amp. Penicillin G 4X 5000000 i.v. for 4 weeks, with other analgetic therapy as needed.

Control native lung RTG on one day after surgery showed a homogeneous shadow in the right basal segment of present effusion, which compared with previous radiographs, is in significantly smaller quantities (Figure 2).

Biochemical analysis on day one after surgery: Glycemia $4,93 \mathrm{mmol} / \mathrm{L}$, CRP 304mg/l, WBC 20,0×10 $/ \mathrm{L}$, Granulocytes 17,8x10 $/$ L, Limfocytes-

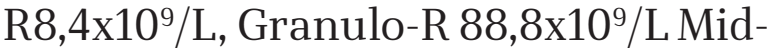

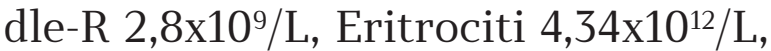
Hemoglobin $123 \mathrm{~g} / \mathrm{L}, \quad$ Hematokrit 35,5\%, MCV 81,8fL, MCH 28,4pg, MCHC 347g/L, PLT 284x109/L.

Control native lung RTG on three days after surgery showed further resorption of pleural effusion (Figure 3).
Biochemical analysis on the same day were: Glycemia $12 \mathrm{mmol} / \mathrm{L}, \mathrm{CRP}$

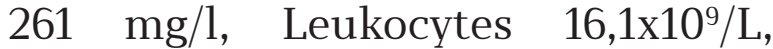
Granulocytes 13,8x109/L, Limfocytes-

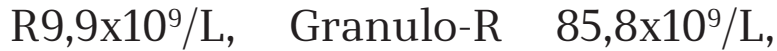
Middle-R4,3×10 $/ \mathrm{L}, \quad$ Eritrociti 4,38 x1012/L, Hemoglobin 120g/L, Hematocrit 35,6\%, MCV 81,2fL, MCH 27,5pg, MCHC 339g/L, PLT 332x109/L.

Our patient has been on the prophylaxis therapy during one year with penicillin preparations. After the completion of therapy, patient's health was quite good as was confirmed by biochemical analyses and control RTG of lungs (Figure 4).

Native lung RTG on one year after surgery (Figure 4):

In the lung parenchyma there were no signs of consolidation or other focal lesions. Frenicocostal sinuses were free.

Biochemical analysis on one year were: Glycemia 7,2mmol/L, CRP $5.47 \mathrm{ng} / \mathrm{dl}$, WBC $7.6 \times 10^{3} / \mu \mathrm{L}$, Neu $5.0 \times$ 103/ $\mu \mathrm{L}$, Limfoc.-R $1,9 \times 10^{3} / \mu \mathrm{L}$, RBC 5.62 x 10\% $/ \mu \mathrm{L}$, Hemoglobin 15.7g/dL, Hematokrit 46,1\%, MCV 82,0fL, MCH 27,9pg,

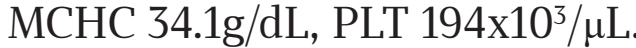

\section{Discussion}

Pulmonary actinomycosis is a bacterial lung infection caused by actinomycosis. In 1857 the first published clinical description of the human form of the disease appeared. The thoracic form was described 25 years later. In 1897 for the first time Actinomycosis israelii, the main species responsible for the human disease, was isolated9. The infection can involve any organ. Pulmonary actinomycosis constitutes $15 \%$ of the total burden of disease $e^{9,10}$. It is now a rare infection, particularly 
in the developed world. The presentation of pulmonary actinomycosis has also changed and it now appears less aggressive in nature compared with the pre-antibiotic era ${ }^{10,11,12}$.

Pulmonary actinomycosis is present at all ages, but there is a clear peak incidence in the $4^{\text {th }}$ and $5^{\text {th }}$ decades of life. The incidence of infection is two to four times greater in males compared with females. A higher incidence of pulmonary actinomycosis has also been reported in patients with poor oral hygiene, underlying respiratory disorders, such as empyema, chronic bronchitis, bronchiectasis, and in alcoholics ${ }^{12}$.

Pulmonary actinomycosis results mostly provoked by the aspiration of oropharyngeal or gastrointestinal secretions into the respiratory tract ${ }^{9,12}$. Cultures are negative in up to $70 \%$ of actinomycosis infections ${ }^{7}$; only $10 \%$ are diagnosed at initial presentation ${ }^{8}$.

Our experience in diagnosis and therapy of lung infections caused by actinomycosis is in concordance with scientific papers published in specialized medical journals.

This disease has excellent prognosis with early detection and proper treatment. Penicillin is the drug of choice over the past 50 years for treatment of pulmonary actinomycosis ${ }^{9}$.

After the isolation of Actinomyces odontolyticus from the tested body specimens of our patient and after adequate surgery intervention combined with penicillin therapy, for a short period of time there was a significant improvement of health status of our patient. This was confirmed by results of control biochemical analysis and control native lung RTG.
Generally, protocols for therapy of Actinomyces odontolyticus suggests 18-24 million units of penicillin per day given for 2-6 weeks followed by oral penicillin or amoxicillin for 8-12 months ${ }^{12}$. Tetracycline and erythromycin are the alternatives in penicillin-allergic patients or pregnant women. Response to treatment should be monitored radiologically with plain radiographs or CT scan ${ }^{12,13}$.

Surgery is very useful if there are complications, such as pulmonary abscesses and empyema, or where discharging fistulas and sinuses may need to be opened, or in some instances, to control life threatening hemoptysis that can occur with pulmonary actinomycosis ${ }^{14,15}$.

During one year treatment with penicillin products, there were no relapse of the infection of our patient and condition is completely normalized as showed by results of control biochemical analysis and control native lung Rtg after one year.

\section{References}

1. Wong VK, Turmezei TD, Weston VC. Actinomycosis BMJ. 2011;53:343.

2. Valour F, Sénéchal A, Dupieux C, Karsenty J, Lustig S, Breton P, et al. Actinomycosis: etiology, clinical features, diagnosis, treatment, and management. Infect Drug Resist 2014;7:183-197.

3. Cone LA, Leung MM, Hirschberg J. Actinomyces odontolyticus bacteremia. Emerg Infect Dis 2003;9(12):1629-32.

4. Felz MW, Smith MR. Disseminated actinomycosis: multisystem mimicry in primary care. South Med J 2003;96(3):294-9.

5. Mandell GL, Bennett JE, Dolin R, edi- 
tors. Mandell, Douglas, and Bennett's Principles and Practice of Infectious Diseases. 7th ed. Philadelphia, PA: Churchill Livingstone Elsevier; 2010.

6. Kakuta R, Hidaka H, Yano H, Miyazaki H, Suzaki H, Nakamura Y, et al. Identification of Actinomyces meyeri actinomycosis in middle ear and mastoid by $16 \mathrm{~S}$ rRNA analysis. J Med Microbiol 2013; 62:1245-48.

7. Mehta D, Statham M, Choo D. Actinomycosis of the temporal bone with labyrinthine and facial nerve involvement. Laryngoscope 2007;117:1999-2001.

8. Oostman O, Smego RA. Cervicofacialactinomycosis: diagnosis and management. Curr Infect Dis Rep 2005;7:170-4.

9. Mabeza GF, Macfarlane J. Pulmonary actinomycosis. Eur Respir J 2003;21(3): 545- 51.

10. Lee JP, Rudoy R. Pediatric thoracic actinomycosis. Hawaii Med J 2003;62(2): 30-2.

11. Brook I. Actinomycosis: diagnosis and management. South Med J 2008;101 (10):1019-23.

12. Farrokh D, Rezaitalab F, Bakhshoudeh B. Pulmonary actinomycosis with endobronchial involvement:A case report and literature review. Tanaffos 2014; 13(1): 52-6.

13. Choi J, Koh WJ, Kim TS, Lee KS, Han J, Kim H, et al. Optimal duration of IV and oral antibiotics in the treatment of thoracic actinomycosis. Chest 2005;128(4): 2211-7.

14. Endo S, Murayama F, Yamaguchi T, Yamamoto S, Otani S, Saito N, et al. Surgical considerations for pulmonary actinomycosis. Ann ThoracSurg 2002;74(1): 185-90.
15. Boudaya MS, Smadhi H, Marghli A, Mouna M, Charmiti F, Ismail O, et al. Surgery in thoracic actinomycosis. Asian CardiovascThorac Ann 2012;20(3): 314- 9. 